\title{
НОВЫЙ МЕТОД СИНТЕЗА 2-АЛКИЛПРОИЗВОДНЫХ 3,4-ДИГИДРОХИНАЗОЛИНОВ
}

\author{
В.В. Малюга, И.Ю. Гришин, А.В. Аксенов, Е.М. Савинская, \\ Д.А. Аксенов, Н.А. Аксенов
}

Химико-Фармацевтический факультет, Северо-Кавказский федеральный университет, 355017, Россия, г. Ставрополь, ул. Пушкина, д. 1.

DOI: 10.19163/MedChemRussia2021-2021-514

E-mails: aaksenov@ncfu.ru, vmaliuga@ncfu.ru

Осуществлен синтез 2-алкилзамещенных 3,4-дигидрохиназолинов из производных 2-аминобензиламинов и 1-нитроалканов, активированных смесью ПФК (87\%) и фосфористой кислот. Данный способ расширяет препаративные возможности использования алифатических нитросоединений в синтезе биологически активных азотистых гететероциклов.

Показано, что в указанной среде фосфорилированная аци-форма нитроалканов, при наличии в о-положении бензиламина второй нуклеофильной $\mathrm{NH}_{2}$ группы, может быть успешно применена для построения хиназолиновой системы путем внутримолекулярной циклоконденсации. Реакция протекает в течение 2 ч при $160{ }^{\circ} \mathrm{C}$. Выход составляет 60-80\%.<smiles>[R]C(N)c1ccccc1N</smiles><smiles>[R1]C[N+](=O)[O-]</smiles>

$\mathrm{R}^{2}=\mathrm{H}, \mathrm{Me}$

$\mathrm{R}^{1}=\mathrm{H}, \mathrm{Me}, \mathrm{Et}, \mathrm{Pr}, \mathrm{Bu}, \mathrm{Am}$<smiles>[R]C1=Nc2ccccc2C([R])N1</smiles>

$60-80 \%$

Исходные о-бензиламинанилин $\left(\mathrm{R}^{2}=\mathrm{H}\right)$ и его метильное производное $\left(\mathrm{R}^{2}=\mathrm{Me}\right)$ были получены превращением о-нитрокабонильных соединений в соответствующие оксимы с последующим их восстановлением либо боргидридом натрия в присутствии $\mathrm{TiCl}_{4}$ в глиме (i), либо цинковой пылью в разбавленной соляной кислоте (ii).<smiles>[R]C(=O)c1ccccc1[N+](=O)[O-]</smiles><smiles>CCOCCN</smiles><smiles>[R]C(=NO)c1ccccc1[N+](=O)[O-]</smiles>

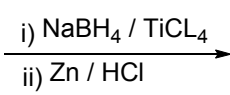<smiles>[R]C(N)c1ccccc1N</smiles>

Строение новых 3,4-дигидрохиназолинов подтверждено данными ${ }^{1} \mathrm{H}$ и ${ }^{13} \mathrm{C}$ ЯМР спектроскопии, масс-спектроскопии с высоким разрешением, а также ИКспектроскопии.

Работа выполнена при финансовой поддержке РФФИ гранты 20-33-90027 аспиранты и 19-03-00308, а также Министерства образования и науки Российской Федерации (тема 0795-2020- 0031). 